\title{
Degassing process of Satsuma-Iwojima volcano, Japan: Supply of volatile components from a deep magma chamber
}

\author{
Kohei Kazahaya, Hiroshi Shinohara, and Genji Saito \\ Geological Survey of Japan, AIST, 1-1-1 Higashi Tsukuba, Ibaraki 305-8567, Japan \\ (Received January 12, 2001; Revised January 17, 2002; Accepted January 17, 2002)
}

\begin{abstract}
Satsuma-Iwojima volcano continuously releases magmatic volatiles from the summit of Iwodake, a rhyolitic lava dome. The temperature of fumaroles is high, between $800^{\circ}$ and $900^{\circ} \mathrm{C}$, and the water-rich composition of volcanic gases has not changed essentially over the past 10 years. Sulfur dioxide flux measured by COSPEC is almost constant with an average of $550 \mathrm{t} / \mathrm{d}$ since 1975 . The present volcanic gas is likely degassed from a rhyolitic magma whose composition is similar to that erupted in 1934, $2 \mathrm{~km}$ east of Satsuma-Iwojima. Comparison of silicate melt inclusions and volcanic gas compositions indicates that the magma degassing pressure is very low, implying magma-gas separation at a very shallow level. The mass rate of magma degassing is estimated at $10 \mathrm{~m}^{3} / \mathrm{s}$ using the volatile content of the magma and the fluxes of magmatic volatiles. The rhyolitic parental magma is volatile-undersaturated in the deep magma chamber, as suggested by melt inclusion studies. Magma convection in a conduit, driven by the density difference between higher density degassed and lower density non-degassed magmas, explains the high emission rate of magmatic volatiles released at shallow depth from such a magma chamber, that is gas-undersaturated at depth. Model calculations require the conduit diameter to be greater than $50 \mathrm{~m}$ as a necessary condition for convection of the rhyolitic magma. Long-term convective degassing has resulted in the rhyolitic magma in the deep chamber to become depleted in volatile components. The melt-inclusion studies indicate that the rhyolitic magma responsible for discharging the present volcanic gas has been degassed during the long degassing history of the volcano and is now supplied with $\mathrm{CO}_{2}$-rich volatile components from an underlying basaltic magma. The total volcanic gas flux over 800 years requires degassing of $80-120 \mathrm{~km}^{3}$ of basaltic magma.
\end{abstract}

\section{Introduction}

A number of passively degassing volcanoes emit large quantities of magmatic volatiles without eruption, i.e., Etna (Allard, 1997), Stromboli (Allard et al., 1994) and IzuOshima (Kazahaya et al., 1994). We can estimate the total amount of the degassed magma if the degassing duration, degassing rate and gas content of the magma are known. These studies show that degassing of volatiles supplied from large magma chambers is necessary to explain the long-term degassing rates. Studies on volatile content of melt inclusions from Satsuma-Iwojima volcano further revealed the degassing evolution of the deep magma chamber (Saito et al., 2001).

Magma convection in a conduit has been proposed as a mechanism responsible for intensive and continuous degassing of magmatic volatiles from magma chambers of basaltic to andesitic volcanoes (Kazahaya et al., 1994). The driving force for convection is the density difference between a dense magma degassed at shallow level and less dense undegassed magma supplied from a deeper level. Shinohara et al. (1995) first modeled magma convection in conduits of silicic systems related to porphyry Mo deposits. Stevenson and Blake (1998) modeled the dynamics of convective magma degassing in a revision of the approach by

Copy right (c) The Society of Geomagnetism and Earth, Planetary and Space Sciences (SGEPSS); The Seismological Society of Japan; The Volcanological Society of Japan; The Geodetic Society of Japan; The Japanese Society for Planetary Sciences.
Kazahaya et al. (1994), in order to model silicic systems, and applied their model to the dacitic Mt. St. Helens magma system. Such modeling indicates that convective degassing is likely a common mechanism in basaltic to dacitic volcanoes (Stevenson and Blake, 1998).

Satsuma-Iwojima volcano is a rhyolitic example of intense and continuous degassing. This study summarizes the volatile study of Satsuma-Iwojima volcano, including $\mathrm{SO}_{2}$ flux measurements and melt inclusion data, and applies the above-mentioned degassing mechanism to the more viscous rhyolitic magma systems of Satsuma-Iwojima volcano.

\section{Outline of Geology}

Mt. Iwodake, the main rhyolitic lava dome on SatsumaIwojima island, is located near the northwestern rim of the submarine Kikai caldera (ca. $18 \mathrm{~km}$ in diameter). This is the youngest caldera in Japan and formed $6300 \mathrm{yr}$ b.p. (Fig. 1). Early in the post-caldera stage, Mt. Iwodake started to erupt, mainly as lava effusions, but sometimes explosively, producing pumice and pyroclastic flows. The latest explosive activity of Mt. Iwodake is dated at $500 \mathrm{yr}$ b.p. (Kawanabe and Saito, 2002). Basaltic activities simultaneously occurred $2 \mathrm{~km}$ distant from Iwodake central crater at about 3000 yr b.p., creating the Inamuradake scoria cone and several basaltic lava flows (Ono et al., 1982). The latest submarine activity occurred in 1934-35, $3 \mathrm{~km}$ east of Iwodake on 500$\mathrm{m}$-deep seafloor, with rhyolitic lava forming Showa-Iwojima Island. 


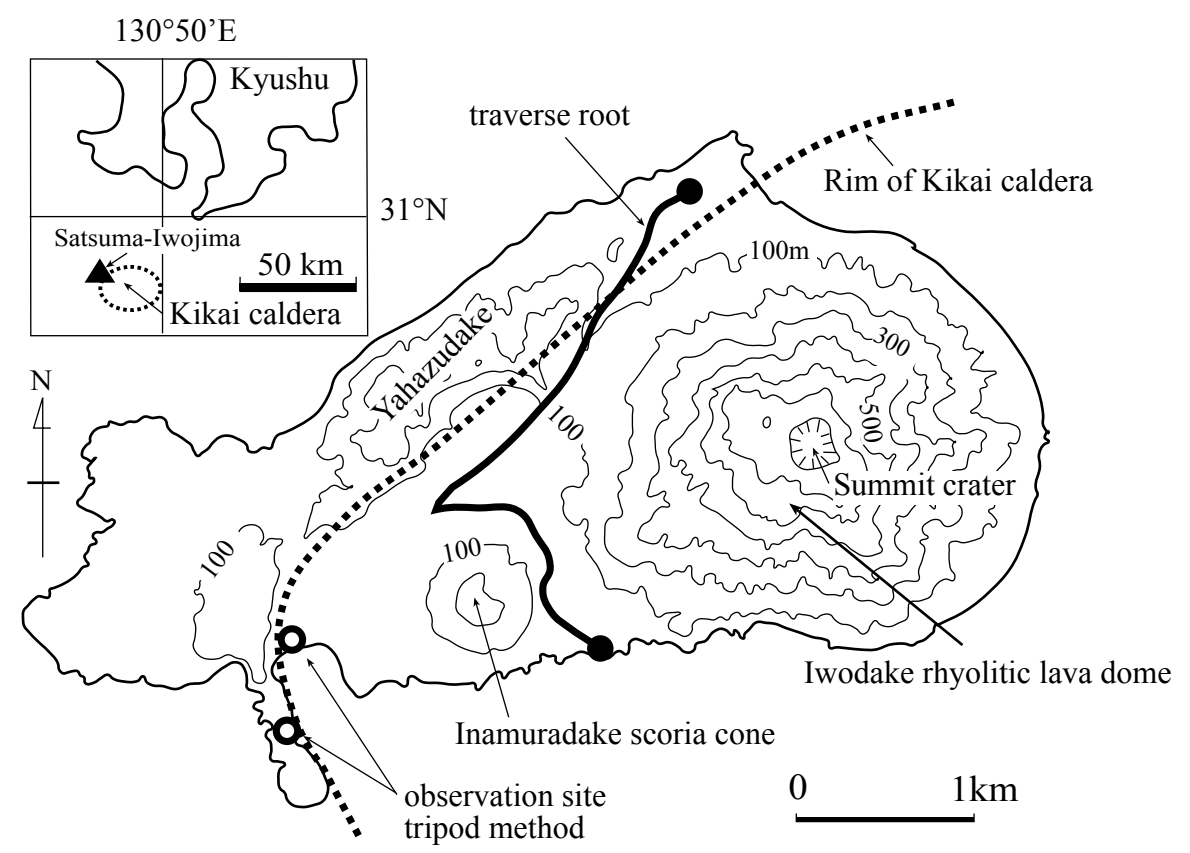

Fig. 1. Topographic map of Satsuma-Iwojima, Kyushu, Japan, showing the location of Iwodake rhyolitic dome and Inamuradake scoria cone. Locations of observation sites for COSPEC measurements by the tripod and the traverse method are also shown.

\section{Magma System}

Saito et al. (2001) measured the chemical and volatile composition of melt inclusions from rhyolites (pumice from caldera-forming eruption and lavas and ashes from the postcaldera stage) and from a basalt (scoria from the postcaldera stage). The post-caldera rhyolites were likely derived from a remnant of the caldera-forming magma, based on the similarity of major-element compositions (Ono et al., 1982; Saito et al., 2001).

Each inclusion has a distinctive volatile composition (Fig. 2; Saito et al., 2001). The Takashima melt inclusions have the highest water concentrations. The saturation pressures based on water and $\mathrm{CO}_{2}$ solubilities are calculated to be $80-180 \mathrm{MPa}$, indicating that a rhyolitic magma chamber existed at 3-7 km depth just before the caldera-forming eruption. The saturation pressure of rhyolitic magma that formed Iwodake, a post-caldera lava dome, was about 70 $\mathrm{MPa}$, corresponding to a depth of about $3 \mathrm{~km}$. Inamuradake basaltic activity simultaneously occurred with Iwodake rhyolitic activity, and the magma-chamber depth is estimated to be $3-5 \mathrm{~km}$ from the saturation pressure of water and $\mathrm{CO}_{2}$ (70-130 MPa). This suggests that a layered magma chamber consisting of upper rhyolitic magma (3-km depth) and lower basaltic magma (3-5 km depth) existed during Iwodake and Inamuradake eruption.

Saito et al. (2002) estimated the temperatures of the magmas using pyroxene geothermometry. Adjacent orthopyroxene and clinopyroxene phenocrysts from Iwodake and Showa-Iwojima rhyolites have compositions that indicate magma temperatures of $960 \pm 28^{\circ} \mathrm{C}$ and $967 \pm 29^{\circ} \mathrm{C}$, respectively, whereas those from Inamuradake basalt showed a temperature of $1125 \pm 27^{\circ} \mathrm{C}$. The relatively high temperature of the rhyolites may have resulted from heating of the rhyolitic magma by the underlying basalt.
Water contents of the rhyolitic melt inclusions show a decreasing trend from older to younger lavas (Fig. 2). Because the major-element composition of the rhyolitic magma was almost constant during the post-caldera stage, the decrease in water content is likely due to degassing. The volatilesaturation pressure of the latest Showa-Iwojima magma, 20-50 MPa (0.5-2 km depth), is too low to represent the real pressure of the magma chamber. The present magma chamber is most likely located at $3-\mathrm{km}$ depth, as estimated from the Iwodake melt-inclusion constraints. As the result of long-term and intense degassing, the Showa-Iwojima magma should be undersaturated with volatiles at the depth of the present rhyolitic magma chamber. However, the melt inclusions from Showa-Iwojima, the latest product of Satsuma-Iwojima volcano, have the highest $\mathrm{CO}_{2}$ concentrations in rhyolites despite their water concentrations and saturation pressures being the lowest. The origin of the high $\mathrm{CO}_{2}$ concentration in this rhyolite is discussed in Section 10.

\section{Volcanic Gases}

Many fumaroles exist in and around the summit. The chemical composition of volcanic gases from the summit crater of Iwodake has been relatively constant since the 1950s (Kamada, 1964) and there has been little change during the past 10 years (Shinohara et al., 2002). Isotopic compositions of the summit volcanic gases indicate that the gases have a magmatic origin (Shinohara et al., 1993; Hedenquist et al., 1994). The highest fumarole temperature measured was $900^{\circ} \mathrm{C}$ in 1994 (Shinohara et al., 2002).

The summit area of the main Iwodake lava dome is strongly silicified by volcanic gases (Hamasaki, 2002), indicating that degassing has continued for a long time. An old manuscript "Heike Monogatari," written about 800 years ago, indicates that intense volcanic gas emission and depo- 


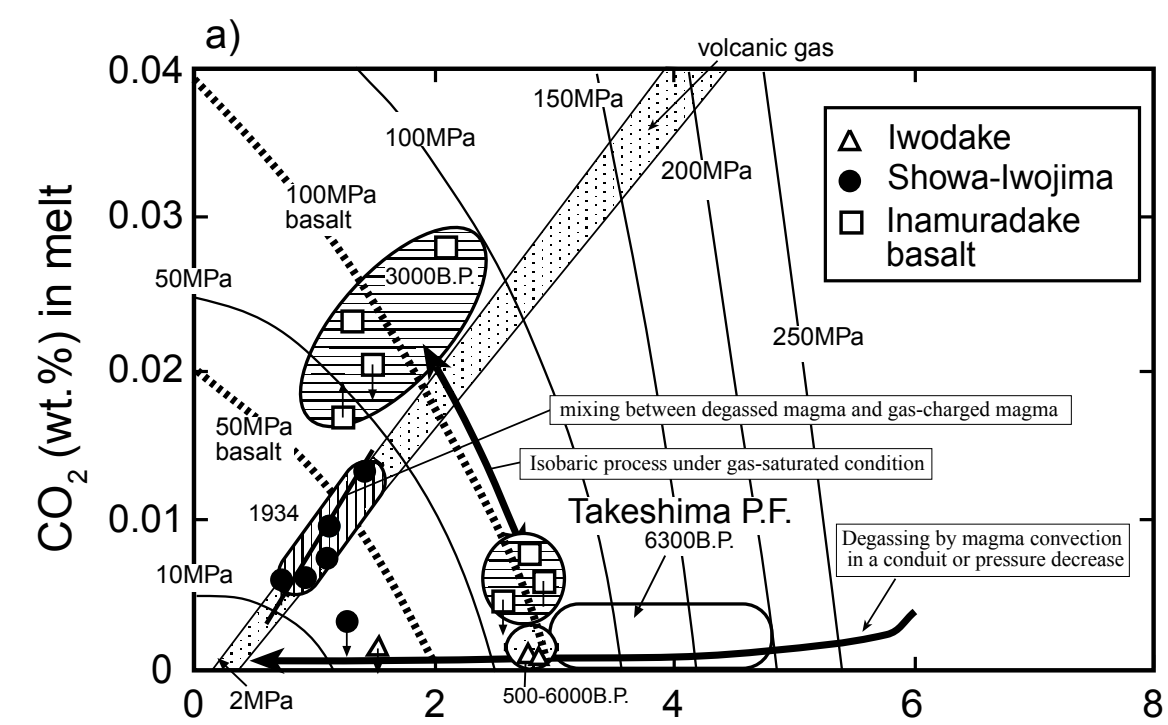

b)

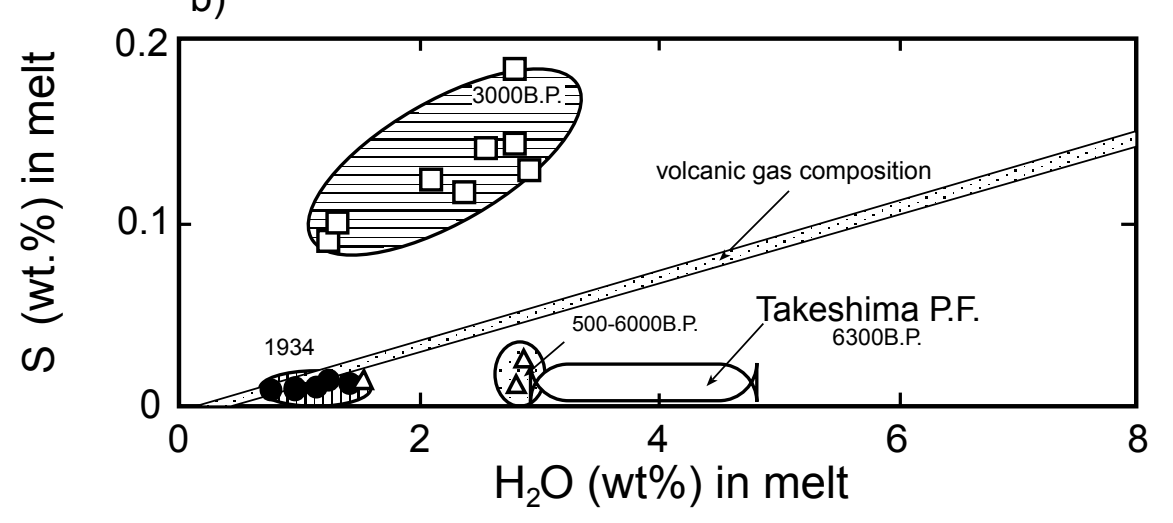

Fig. 2. Volatile composition of melt inclusions in pumices from Takeshima and Iwodake pyroclastic flows, scoria from Inamuradake and pumicious lava from Showa-Iwojima (revised from Saito et al., 2001). a) $\mathrm{H}_{2} \mathrm{O}$ and $\mathrm{CO}_{2}$, b) $\mathrm{H}_{2} \mathrm{O}$ and S. Isobaric solubility curves are drawn using solubilities of $\mathrm{H}_{2} \mathrm{O}$ in rhyolite at $1000^{\circ} \mathrm{C}$ (Miyagi et al., 1997), $\mathrm{H}_{2} \mathrm{O}$ in basalt at $1100^{\circ} \mathrm{C}$ (Burnham, 1979), $\mathrm{CO}_{2}$ in rhyolite at $1200^{\circ} \mathrm{C}$ (Fogel and Rutherford, 1990 ) and $\mathrm{CO}_{2}$ in basalt at $1200^{\circ} \mathrm{C}$ (Stolper and Holloway, 1988). The dotted area indicates the range of $\mathrm{CO}_{2} / \mathrm{H}_{2} \mathrm{O}$ and $\mathrm{S} / \mathrm{H}_{2} \mathrm{O}$ ratios of high temperature volcanic gases at the summit crater (Shinohara et al., 2002). This area is drawn assuming that magma does not degas all its $\mathrm{H}_{2} \mathrm{O}$ even at low-pressure conditions, as usually found from the lava compositions.

sition of sulfur already existed at that time (Kamada, 1964). Therefore, volcanic gases have discharged for greater than 800 years from the summit crater of Iwodake.

\section{Source of Volcanic Gases}

Long-term intense discharge of volcanic gases from Iwodake implies that the underlying magma chamber is relatively degassed. Since the chemical composition of the melt inclusions in the rhyolites from Satsuma-Iwojima volcano is rhyolitic, these inclusions most likely represent the parental rhyolitic magma chamber at depth. The $\mathrm{CO}_{2} / \mathrm{H}_{2} \mathrm{O}$ ratio of the volcanic gas is found to be similar to that dissolved in the melt inclusions from the Showa-Iwojima and the Inamuradake melt inclusions (Fig. 2), and it is strongly suggested that volcanic gas comes from either residual portion of the Showa-Iwojima rhyolitic magma or Inamuradake basaltic magma.

Saito et al. (2001) measured the sulfur and chlorine contents of melt inclusions, and found that the Showa-Iwojima melt inclusions have $\mathrm{S} / \mathrm{H}_{2} \mathrm{O}$ ratios similar to the volcanic gases. By contrast, the Inamuradake melt inclusions contain several times more sulfur than that expected on the basis of the volcanic gas composition (Fig. 2). As the composition of volcanic gas has been almost constant over the past 10 years (Shinohara et al., 2002), a stable degassing system is likely to exist. This implies that the volcanic gases are emitted from magma with a constant volatile content and constant degassing pressure.

For the following reasons, we assume that the present volcanic gas is released from a rhyolitic magma with a volatile content similar to the Showa-Iwojima magma (erupted 67 years ago), rather than from a basaltic magma:

1) Basaltic to andesitic magma has never erupted from the Iwodake lava dome.

2) Less-dense rhyolitic magma may still be located in the upper part of a magma chamber above basaltic magma. Therefore, degassing of magmatic gases directly from an underlying basaltic magma is unlikely.

3) The high fumarolic temperature $\left(900^{\circ} \mathrm{C}\right)$ is close to the temperature of the Showa-Iwojima rhyolite, estimated 
from the two pyroxene geothermometer $\left(967-990^{\circ} \mathrm{C}\right.$; Saito et al., 2002). Thus, basaltic magma is not necessary to explain the high fumarole temperatures.

4) The Showa-Iwojima melt inclusions have volatile compositions that are more similar to the volcanic gases than those of the Inamuradake melt inclusions. The high fumarolic temperature also suggests a low pressure of degassing, and in this situation the volcanic gas composition should be close to the volatile composition of the magma. In particular, the Inamuradake melt inclusions have excessive sulfur concentrations to conclude that the sulfur in volcanic gases is directly derived from the Inamuradake magma.

Therefore, the present volcanic gas is most likely released from a rhyolitic magma similar in composition to that of Showa-Iwojima magma, rather than from the basaltic magma underlying the rhyolitic magma.

\section{Sulfur Dioxide Flux Measurements}

The first sulfur dioxide flux measurement by COSPEC III was performed in 1975 by the seaborne traverse method, measuring 570 t/d (Ohkita et al., 1977). We measured $\mathrm{SO}_{2}$ flux since 1990 using COSPEC V with the ground-based tripod method and the traverse method using a vehicle. During COSPEC measurement, volcanic plume movement was monitored by a video camera to determine the wind velocity. The results for the COSPEC measurements are summarized in Table 1.

For the tripod method, we used an automatic tilting mount and $\mathrm{SO}_{2}$ flux was monitored every minute. As the volcanic plume was horizontal, during the monitoring, a vertical scan of the plume was performed during all the tripod measurements. The baseline changed during vertical

Table 1. Sulfur dioxide flux from the Iwodake summit measured by COSPEC with the tripod and the traverse methods.

\begin{tabular}{lccc}
\hline \multicolumn{1}{c}{ Date } & \multicolumn{3}{c}{$\mathrm{SO}_{2}$ flux (t/d) } \\
& min. & max. & ave. \\
\hline 1990.10 .27 & 430 & 540 & 470 \\
1994.10 .30 & 420 & 880 & 640 \\
1996.10 .16 & 210 & 900 & 460 \\
1997.4 .20 & 230 & 750 & 470 \\
1997.4 .21 & 470 & 1100 & 750 \\
1998.11 .8 & 120 & 600 & 320 \\
\hline & \multicolumn{3}{c}{ traverse method } \\
\hline $1975.2 .12^{*}$ & 510 & 620 & 570 \\
$1995.10 .21^{* *}$ & $(1370)$ & $(2070)$ & $(1760)$ \\
$1997.4 .20^{* *}$ & $(920)$ & $(1430)$ & $(1210)$ \\
$1997.4 .21^{* *}$ & $(1460)$ & $(1600)$ & $(1530)$ \\
\hline average & \multicolumn{3}{c}{550} \\
\hline * measured by Ohkita et al. $(1977)$ using a boat. \\
**measured using a vehicle. values are not used (see text).
\end{tabular}

scanning, mainly due to the UV intensity variation in the scan range between low and high angles. Therefore, we always corrected for this effect by using background $\mathrm{SO}_{2}$-free data, determined in a direction without any volcanic plume. As the observation points were restricted on the island, we sometimes found that part of the volcanic plume was hidden behind the flank of Iwodake. Such data underestimated the flux and were omitted from Table 1.

The flux values obtained by the traverse method are always higher than those obtained by the tripod method. On Satsuma-Iwojima, the traverse route is restricted to a road from southwest to northwest sites (Fig. 1). The route follows the valley between Inamuradake cone and Yahazudake caldera wall. Because of the topography, part of the plume is likely trapped and stagnant in the valley when the wind blows in the SW to NW directions. This causes an overestimation of the $\mathrm{SO}_{2}$ flux during the traverse method, because COSPEC measures the $\mathrm{SO}_{2}$ signal not only from the flowing plume but also from the trapped plume. Thus, we use only the $\mathrm{SO}_{2}$ flux value obtained by the tripod method.

The $\mathrm{SO}_{2}$ flux from the Iwodake summit crater varied between 320 and $750 \mathrm{t} / \mathrm{d}$ with the average flux of $550 \mathrm{t} / \mathrm{d}$ during the monitoring period from 1990 to 1998. Fluxes of other magmatic volatiles can be estimated using the chemical composition of the volcanic gases (Shinohara et al., 2002) from the summit of Iwodake. These are $16000 \mathrm{t} / \mathrm{d}$ for water and $150 \mathrm{t} / \mathrm{d}$ for $\mathrm{CO}_{2}$ (Table 2). The magmatic volatile flux condensed into groundwater and discharged from hot springs has been neglected. Therefore, these are minimum flux values from the Satsuma-Iwojima volcano.

\section{Volatile Budget}

We can calculate the mass rate of magma degassing using the magmatic volatile fluxes and volatile content of the Showa-Iwojima magma. A water content of $1 \mathrm{wt} \%$ is used for the following calculation, because the highest water value of the Showa-Iwojima magma is $1.4 \mathrm{wt} . \%$ from melt inclusion analyses (Saito et al., 2001), and some water is retained in the magma. The mass rate of magma degassing calculated on the basis of individual species, $\mathrm{H}_{2} \mathrm{O}, \mathrm{CO}_{2}$ and $\mathrm{S}$, varies in the range $17,000-30,000 \mathrm{~kg} / \mathrm{s}$ or $7.5-13 \mathrm{~m}^{3} / \mathrm{s}$, assuming complete degassing for $\mathrm{S}$ and $\mathrm{CO}_{2}$ (Table 2). The average value of $22,000 \mathrm{~kg} / \mathrm{s}(1.9 \mathrm{Mt} / \mathrm{d})$ or $10 \mathrm{~m}^{3} / \mathrm{s}$ is used in the following discussion for the mass rate of magma degassing.

Since degassing is believed to have continued for more than 800 years (Yoshida and Ozawa, 1981), the estimate of the volume of degassed magma is $250 \mathrm{~km}^{3}$, if all the gases were initially contained in the rhyolitic magma. This calculation assumes that the composition of volcanic gas and volatile content of magma has been constant over 800 years; however, there is no evidence to check this assumption. The volatile content of the Showa-Iwojima magma used in the above calculation is the highest value. Therefore, the $250 \mathrm{~km}^{3}$ estimate for total volume of degassed magma is a minimum. The trend in volatile content of magmas over the past 6300 years (Fig. 2) also indicates that degassing of the magma chamber occurred during the post-caldera stage (Saito et al., 2001). Consequently, long-term degassing of a rhyolitic magma chamber might be required. 
Table 2. High temperature volcanic gas composition, flux and melt inclusion concentration of $\mathrm{H}_{2} \mathrm{O}, \mathrm{CO}_{2}$ and $\mathrm{SO}_{2}$, and mass rate of the magma degassing calculated for each species.

\begin{tabular}{lcccc}
\hline & $\mathrm{H}_{2} \mathrm{O}$ & $\mathrm{CO}_{2}$ & $\mathrm{SO}_{2}$ & \\
\hline Mean chemical composition $(\mathrm{mol} \%)^{*}$ & 97.4 & 0.037 & 0.093 & \\
Flux (t/d)** & 16000 & 150 & 550 & \\
degassed from melt (wt\%)*** & 1 & 0.010 & 0.021 & average \\
Mass rate of magma degassing & & & & 10 \\
$\left(\mathrm{~m}^{3} / \mathrm{s}\right)$ & 8.2 & 7.5 & 13.1 & 22000 \\
$(\mathrm{~kg} / \mathrm{s})$ & 19000 & 17000 & 30000 & \\
\hline
\end{tabular}

*average of high temperature volcanic gas calculated from the data given by Shinohara et al. (2002).

** calculated using $\mathrm{SO}_{2}$ flux $(550 \mathrm{t} / \mathrm{d})$ and the mean chemical composition.

*** reduced from the melt inclusion data given by Saito et al. (2001). See text.

\section{Degassing Mechanism}

Degassing of magma requires oversaturation of volatiles in a melt. Therefore, degassing occurs only at relatively low-pressure conditions. However, the magma chamber is concluded to be located at a relatively high pressure, greater than $3 \mathrm{~km}$ for Satsuma-Iwojima volcano (Saito et al., 2001). Therefore, a huge amount of magmatic volatiles must be transported from such a deep magma chamber towards the surface. Because the volcanic gases from the fumaroles collected at the summit crater are water-rich $(>97 \%)$ and of magmatic origin (Shinohara et al., 1993; Hedenquist et al., 1994), the degassing pressure must be low enough to degas water efficiently from the parental magma. As mentioned earlier, the highest fumarolic temperature of $900^{\circ} \mathrm{C}$ also supports the idea that volcanic gases were released from the magma at shallow depths. Therefore, it is necessary that the magma chamber system is connected to the surface by an open conduit and water-rich magmatic gases are separated at shallow depths. As effective water degassing from magma only occurs at shallow depths, water must be transported from a deep magma chamber either as bubbles or water-bearing magma. Because the Showa-Iwojima magma is likely to be undersaturated in volatiles at the depth of the magma chamber, water transport by bubbles not possible.

Water transport by volatile-bearing magma is possible as the result of magma convection in a conduit (Kazahaya et al., 1994). When a magma conduit extends to a shallow level and is allowed to degas, the upper-most part of the magma may then degas efficiently. Density of the degassed magma increases by bubble separation and melt degassing, which makes the lower part of undegassed magma buoyant, and the degassed magma descend through the conduit.

\section{Rhyolitic Magma Convection in a Conduit}

In this section, we discuss whether convection of the Showa-Iwojima rhyolitic magma could occur in an open conduit system with a sufficient rate to account for the observed degassing rate. The degassing rate induced by magma convection in a conduit is controlled by two processes: 1) the rate of counter flow in a magma conduit, and 2) bubble separation rate at the top of the conduit. The first process can be evaluated by fluid dynamic model. Stevenson and Blake (1998) provided fluid dynamic equa- tions for magma convection in conduits based on experiments and theory, revising the treatment by Kazahaya et al. (1994):

$$
Q=\pi\left(R^{*}\right)^{2} \operatorname{Ps}\left(g \Delta \rho R^{4} / \mu_{d}\right),
$$

where $R^{*}\left(=R_{a} / R_{c}\right)$ is the dimensionless radius of the rising flow and Ps is the Poiseuille number (Koyaguchi and Blake, 1989). Viscosity values for degassed magma with a water concentration of $0.4 \mathrm{wt} . \%\left(\mu_{d}\right)$, and undegassed magma with a water concentration of $1.4 \mathrm{wt} . \%\left(\mu_{c}\right)$, are calculated with the method of Persicov (1990). The viscosity of rhyolitic magma using the chemical composition of lava of Showa-Iwojima (Ono et al., 1982) is $10^{6.1} \mathrm{~Pa} \cdot \mathrm{s}$ and $10^{4.9} \mathrm{~Pa} \cdot \mathrm{s}$ at $1000^{\circ} \mathrm{C}$, respectively. The Ps is constant at a value of 0.064 when $\mu_{d} / \mu_{c}>12$ (Stevenson and Blake, 1998), and Ps of 0.064 is used for calculation. An $R^{*}$ value of 0.6 is used according to the experiments by Stevenson and Blake (1998). Degassing of $1 \mathrm{wt} . \%$ water results in a density difference of about $50 \mathrm{~kg} / \mathrm{m}^{3}$, calculated from the method of Lange and Carmichael (1987). This density difference drives the magma convection in a conduit (Fig. 3). The diameter of the magma conduit obtained is $50 \mathrm{~m}$ using Eq. (1). This conduit diameter is realistic, based on estimations of conduit diameters at other volcanoes (80-120 m for Mt. St. Helens in 1980; Stevenson and Blake, 1998).

Another rate control factor for magma convection is the separation process of the bubbles from magma. This process might be very important for non-explosive eruption such as dome-forming eruptions. Formation of permeable foam in an ascending silicic magma would induce gas loss in a shallow conduit prior to eruption (Eichelberger et al., 1986; Westrich and Eichelberger, 1994). Melnik and Sparks (1999) showed theoretically that gas exsolution of a silicic melt at shallow depth causes crystallization of magma during its ascent, and the effective gas release occurs through a permeable magma column. Although the above-mentioned process was modeled for dome-forming eruptions, it is applicable to degassing of a convecting magma, because the degassing process occurs in a shallow conduit prior to eruption and is controlled mainly by decompression rate and viscosity.

There are some volcanoes that have erupted effusively with an emission rate of volcanic gases similar to Satsuma- 


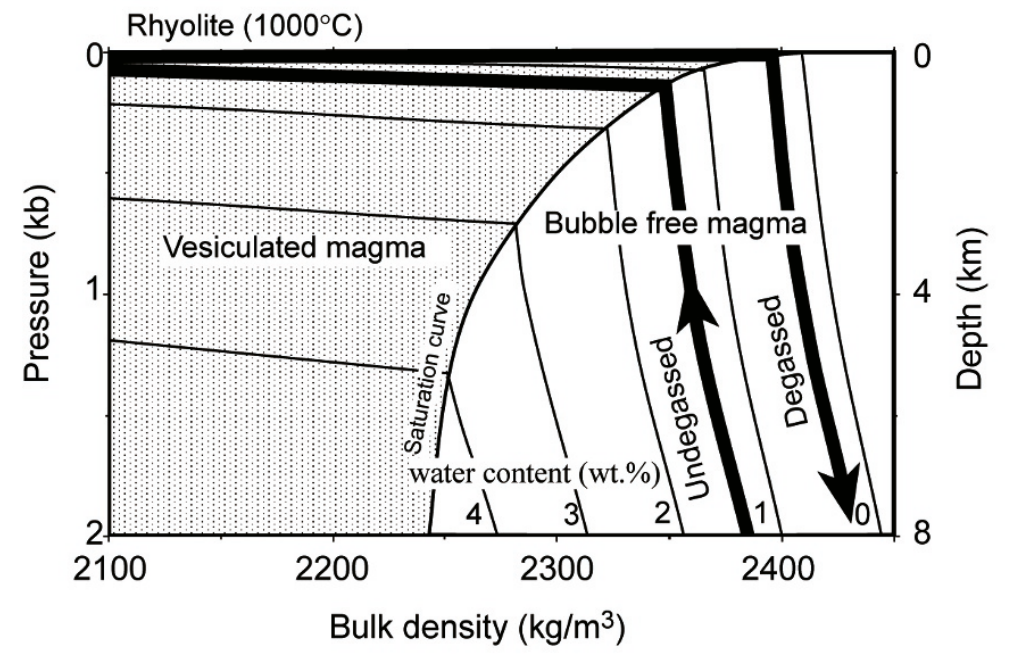

Fig. 3. Density changes of ascending undegassed magma and descending degassed magma as a function of pressure (depth) for the Showa-Iwojima rhyolitic composition at $1000^{\circ} \mathrm{C}$. Arrow shows a path for the convective transport of magma. Numbers are water content in wt.\%. The solubility curve is from Miyagi et al. (1997). Densities were calculated based on Lange and Carmichael (1987).

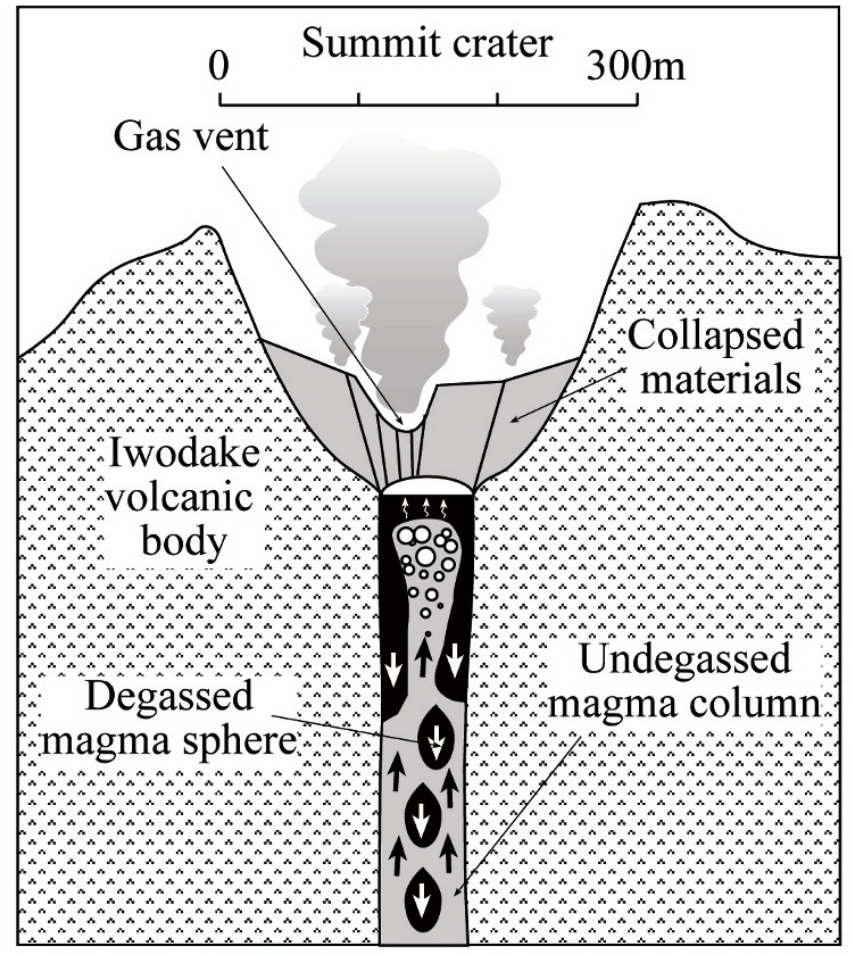

Fig. 4. Model of magma convection in a conduit at shallow depth. The flow style of degassed magma descending as spheres through the undegassed magma was originally suggested by Stevenson and Blake (1998) based on experiments with a parameter $12<\mu_{d} / \mu_{c}<300$.

Iwojima. For example, during the 1991 eruption of Unzen volcano, the highest emission rates of magma and $\mathrm{SO}_{2}$ were $7 \mathrm{~m}^{3} / \mathrm{s}$ (Nakada and Motomura, 1999) and $240 \mathrm{t} / \mathrm{d}$ (Hirabayashi et al., 1995), respectively. The effusion rate of dacite magma at Unzen volcano is very close to the mass rate of magma degassing for Satsuma-Iwojima of $10 \mathrm{~m}^{3} / \mathrm{s}$. The estimated viscosity of Satsuma-Iwojima rhyolitic magma is not particularly high $\left(\sim 10^{5} \mathrm{~Pa} \cdot \mathrm{s}\right)$, and is comparable to that of typical andesitic to dacitic magmas, including the Unzen magma. As the Unzen magma obviously degassed large amounts of volatiles without explosions, the Showa-Iwojima magma might also be able to degas at a similar mass rate, because of the similarities in magmatic and flow parameters. Finally, we conclude that degassing as the result of rhyolitic magma convection in a conduit may occur at SatsumaIwojima volcano. This is consistent with the occurrence of high-temperature fumaroles, high emission rate of magmatic gases and the long duration of degassing.

Stevenson and Blake (1998) performed experimental studies on the style of fluid convection when the viscosity ratio $\left(\mu_{d} / \mu_{c}\right)$ is between 10 and $300 \mathrm{~Pa} \cdot \mathrm{s}$. A possible style of degassing-induced magma convection in a conduit is illustrated in Fig. 4, based on the experiments by Stevenson and Blake (1998). The magma is hypothesized to lie very close to the bottom of the crater, near the location of the pressure source of low-frequency earthquakes as estimated by particle-motion analyses of broadband seismic data (Ohminato and Ereditato, 1997).

\section{Volatile Transport from Basalt to Rhyolite}

Showa-Iwojima magma has relatively higher $\mathrm{CO}_{2}$ and lower $\mathrm{H}_{2} \mathrm{O}$ contents than the other older magmas (Fig. 2). Long-term degassing during magma convection in a conduit could cause volatile undersaturation of the magma in the deep chamber. However, the high $\mathrm{CO}_{2}$ content cannot be explained by degassing, because $\mathrm{CO}_{2}$ is the less soluble species and the most readily degassed. Volatile supply from a mafic magma system to a silicic magma system has been suggested (e.g., Wallace et al., 1995; Wallace, 2001) to explain the excess sulfur degassing during explosive eruptions.

In the case of Satsuma-Iwojima, however, $\mathrm{CO}_{2}$ supply from basalt could be accompanied by $\mathrm{H}_{2} \mathrm{O}$ but not by sulfur compounds, because of the low $\mathrm{S}$ content in the ShowaIwojima rhyolite. Therefore, the volatile transport mechanism might be different from that suggested for other volcanoes. The transport mechanism of $\mathrm{CO}_{2}$ from basalt to rhyo- 


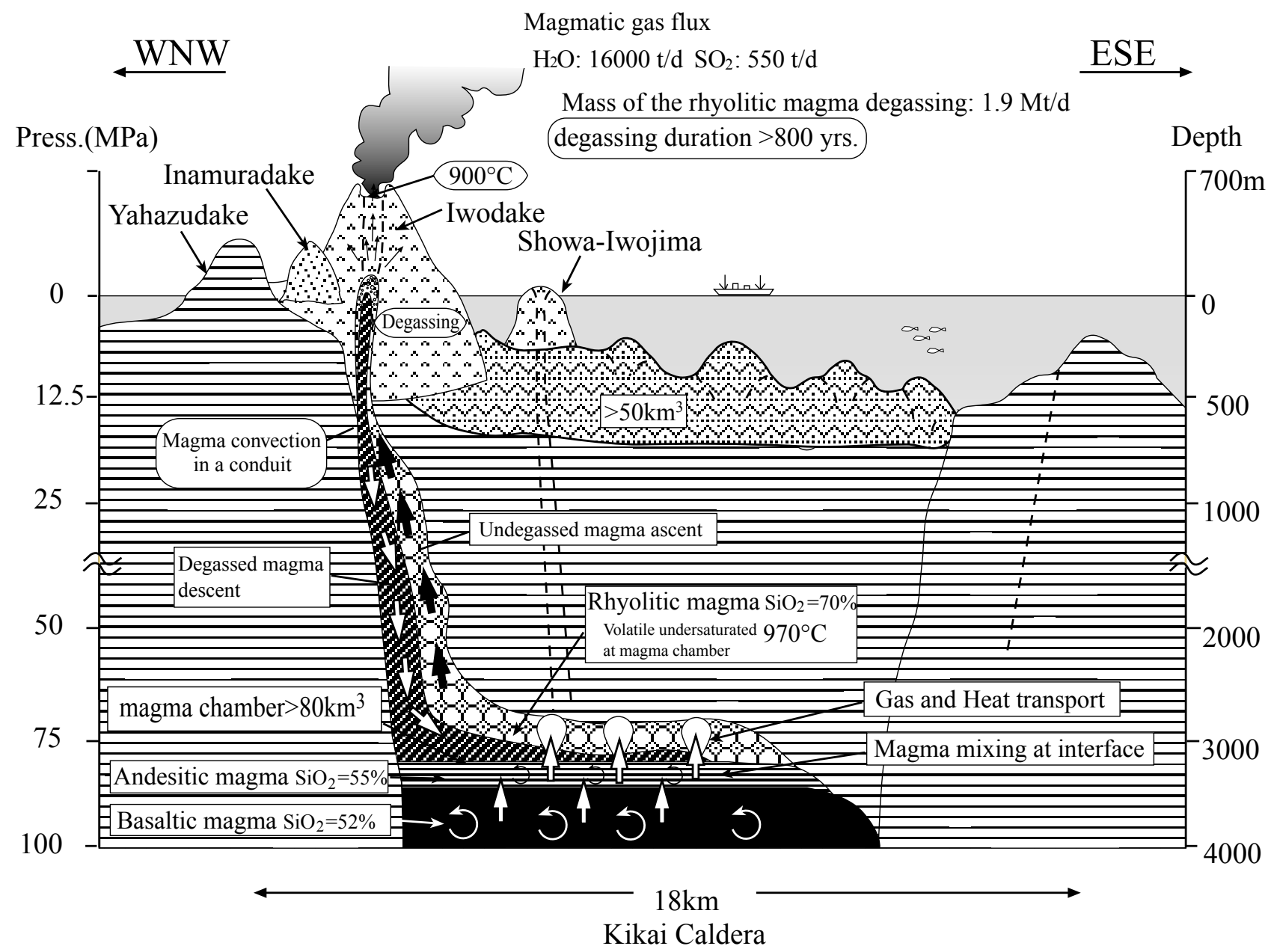

\begin{tabular}{|c|c|c|c|}
\hline & $\begin{array}{l}\text { volcanic body including pre- } \\
\text { caldera product and basement }\end{array}$ & $8 \times 8 \times 80$ & gas-charged rhyolitic magma \\
\hline 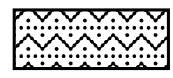 & $\begin{array}{l}\text { submarine post-caldera } \\
\text { lava domes }\end{array}$ & OU⿻ & degassed rhyolitic magma \\
\hline 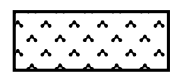 & $\begin{array}{l}\text { Iwodake and Showa-Iwojima, } \\
\text { post-caldera lava dome }\end{array}$ & & $\begin{array}{l}\text { andesitic layer made by mixing } \\
\text { of upper rhyolite and basal basalt }\end{array}$ \\
\hline$\because$ & $\begin{array}{l}\text { Inamuradake, } \\
\text { post-caldera scoria cone }\end{array}$ & & basaltic magma \\
\hline
\end{tabular}

Fig. 5. Schematic illustration of magma system of Satsuma-Iwojima volcano (vertically exaggerated). The pressure of the basaltic magma and chemical compositions of the magma are from Saito et al. (2001). See text for details.

lite is not yet clear, but may result from bubble migration or diffusion in the deep chamber. Bubble migration can transport volatiles oversaturated at the chamber pressure. Therefore, the transported volatles should be rich in $\mathrm{CO}_{2}$ and poor in $\mathrm{H}_{2} \mathrm{O}$. As the solubility of sulfur compounds in a $\mathrm{CO}_{2}-$ rich gas phase is not yet known, the $\mathrm{S}$ content in the bubbles might be very low. This possibility is consistent with the present model but is not consistent with the commonly accepted hypothesis of sulfur supply mechanism (e.g., Wallace et al., 1995; Wallace, 2001). In contrast, transport of $\mathrm{CO}_{2}$ and $\mathrm{H}_{2} \mathrm{O}$ may also be caused by diffusion, which is driven by the activity gradient of a component. As sulfide solu- bility in silicate melt is much higher in a basaltic melt than in a rhyolitic melt (Carroll and Webster, 1994), the activity gradient of sulfur between a basalt and a rhyolite may be so small that little sulfur diffusion can take place.

Snyder and Tait (1998) theoretically modeled the chemical interaction caused by input of basalt to a more silicic magma chamber based on a flow-enhanced diffusive transport model, and concluded that diffusive exchange between silicic and basaltic magmas is easier to occur than that has been thought previously. If the diffusive exchange occurs between the degassed rhyolite and gas-bearing basalt, volatile transport from the basalt to the silicic magma would 
occur. This process can explain the volatile supply to the magma chamber system of Satsuma-Iwojima. Long-term convective degassing results in the upper rhyolitic magma in the chamber becoming degassed, and the volatiles contained in the underlying basaltic magma could be transported into the upper degassed rhyolite.

The diffusion hypothesis can explain not only the $\mathrm{CO}_{2}$ supply mechanism but also variation of volatile composition in the Showa-Iwojima magma that seems to lie along a straight line originating from $0.1-0.4$ wt. $\% \mathrm{H}_{2} \mathrm{O}$ and zero $\mathrm{CO}_{2}$ (Fig. 2). This volatile-poor composition could result from degassing at a low pressure of $0.5-3.0 \mathrm{MPa}$ that might correspond to the degassing pressure at the top of convecting magma. As neither degassing nor crystallization can create such a variation along a straight line that does not pass through the origin, the variation is most likely created by mixing between volatile-poor rhyolite and volatile-rich rhyolite. The volatile-rich rhyolite might be created by volatile and heat supply from basalt.

The present rhyolitic magma is thought to have fully degassed its original volatiles, such as noted from the Iwodake magma or the Takeshima magma. It acts only as the carrier of volatile components from the underlying basaltic magma to the surface. The estimated mass of the degassed magma of $250 \mathrm{~km}^{3}$ does not represent a real volume of the rhyolite in the chamber, but that circulated through the conduit. Inamuradake basalts contain $\mathrm{H}_{2} \mathrm{O} 2-3$ wt. $\%$, obtained by melt inclusion study (Saito et al., 2001). Assuming that all the magmatic water flux of $16000 \mathrm{t} / \mathrm{d}$ (Table 2) was supplied from a basalt with this $\mathrm{H}_{2} \mathrm{O}$ content, we can estimate the total mass of degassed basaltic magma to be $80-120 \mathrm{~km}^{3}$ over the past 800 years.

\section{Summary}

A schematic model is shown in Fig. 5, which summarizes the present magma system of Satsuma-Iwojima volcano deduced from the volatile studies (Shinohara et al., 1993, 2002; Kazahaya and Shinohara, 1996; Saito et al., 2001, 2002) and $\mathrm{SO}_{2}$ flux studies. Combination of repeat $\mathrm{SO}_{2}$ flux measurements using COSPEC and chemistry of volcanic gases (Shinohara et al., 2002) indicate an average flux of volatiles of $550 \mathrm{t} / \mathrm{d} \mathrm{SO}_{2}, 16,000 \mathrm{t} / \mathrm{d}$ water and 150 $\mathrm{t} / \mathrm{d} \mathrm{CO}_{2}$. Based on studies of melt inclusions and mafic inclusions of the Satsuma-Iwojima magmas, a layered magma chamber is suggested to exist (Saito et al., 2001, 2002). The depth of the basaltic and rhyolitic magmas in the chamber is estimated to be $3-5 \mathrm{~km}$ and $3 \mathrm{~km}$, respectively (Saito et al., 2001).

The Showa-Iwojima magma erupted in 1934-35, is likely representative of the present degassing magma at depth, because of the similarity between the volcanic gas composition and the volatile composition of its melt inclusions. Carbon dioxide concentration of the Showa-Iwojima melt inclusions is the highest in the rhyolitic melt inclusions, despite the water concentrations being the lowest. The $\mathrm{CO}_{2}$ in the ShowaIwojima magma is thought to be supplied from the basaltic magma located beneath the rhyolitic magma. The volatile transport from the underlying basaltic magma to the upper rhyolitic magma must occur at the rate of volatile emissions from the summit. Thus, the rhyolitic magma acts as the volatile transporter through the process of magma convection in a conduit. This magma convection is driven by the density difference between degassed and undegassed magmas. The degassing has continued over at least the past 800 years. An estimate for the total amount of the degassed magma produced during this time is $80-120 \mathrm{~km}^{3}$, assuming that the chamber degasses magma with a water of 23 wt.\%, corresponding to the water content of the Inamuradake basaltic magma.

This process of magma convection in a conduit will work until the whole magma chamber is degassed, which includes both the rhyolitic and basaltic magmas. The convective degassing model presented here is plausible even for a rhyolitic magma system, and is consistent with the results by volatile studies, such as compositions of volcanic gases and melt inclusions, and the emission rate of magmatic gases. The specific mechanism of volatile supply from the basaltic magma to the upper rhyolitic magma is still unclear.

Acknowledgments. We thank Mishima-mura city office for supporting the COSPEC measurements by providing electricity and observation sites. We also thank Prof. J. Hirabayashi who kindly permitted us to use his COSPEC instrument for the 1990 measurements. This paper was greatly improved with critical and constructive comments from Drs. J. B. Lowenstern, P. Wallace, and J. W. Hedenquist.

\section{References}

Allard, P., Endogenous magma degassing and storage at Mount Etna, Geophys. Res. Lett., 24, 2219-2222, 1997.

Allard, P., J. Carbobbelle, N. Metrich, H. Loyer, and P. Zettwoog, Sulfur output and magma degassing budget of Stromboli volcano, Nature, 368, 326-330, 1994.

Burnham, C. W., Magmas and hydrothermal fluids, in Geochemistry of Hydrothermal Ore Deposits, edited by H. Barnes, 2nd ed., pp. 71-136, John Wiley \& Sons, New York, 1979.

Carroll, M. R. and J. D. Webster, Solubilities of sulfur, noble-gases, nitrogen, chlorine, and fluorine in magmas, Volatiles in Magmas, Rev. Mineral., 30, edited by M. R. Carroll and J. R. Holloway, pp. 231-279, Mineral. Soc. Am., Washington, 1994.

Eichelberger, J. C., C. R. Carrigan, H. R. Westrich, and R. H. Price, Nonexplosive silicic volcanism, Nature, 323, 598-602, 1986.

Fogel, R. A. and M. J. Rutherford, The solubility of carbon dioxide in rhyolitic melts: a quantitative FTIR study, Am. Mineral., 75, 1311-1326, 1990.

Hamasaki, S., Volcanic-related alteration and geochemistry of Iwodake volcano, Satsuma-Iwojima, Kyushu, SW Japan, Earth Planets Space, 54, this issue, 217-229, 2002.

Hedenquist, J. W., M. Aoki, and H. Shinohara, Flux of volatiles and oreforming metals from the magmatic-hydrothermal system of Satsuma Iwojima volcano, Geology, 585-588, 1994.

Hirabayashi, J., T. Ohba, K. Nogami, and M. Yoshida, Discharge rate of $\mathrm{SO}_{2}$ from Unzen volcano, Kyushu, Japan, Geophys. Res. Lett., 22, 1709 $1712,1995$.

Kamada, M., Volcano and geothermy of Iwo-jima, Kagoshima prefecture, Jinetsu, 3, 1-23, 1964 (in Japanese).

Kawanabe, Y. and G. Saito, Volcanic activity of the Satsuma-Iwojima area during the past 6500 years, Earth Planets Space, 54, this issue, 295-301, 2002 .

Kazahaya, K. and H. Shinohara, Excess degassing of active volcanoes: processes and mechanisms, Mem. Geol. Soc. Japan, 46, 91-104, 1996 (in Japanese with English abstract).

Kazahaya, K., H. Shinohara, and G. Saito, Excessive degassing of IzuOshima volcano: magma convection in a conduit, Bull. Volcanol., 56, 207-216, 1994.

Koyaguchi, T. and S. Blake, The dynamics of magma mixing in a rising magma batch, Bull. Volcanol., 52, 127-137, 1989.

Lange, R. and I. S. E. Carmichael, Densities of $\mathrm{Na}_{2} \mathrm{O}-\mathrm{K}_{2} \mathrm{O}-\mathrm{CaO}-\mathrm{MgO}$ $\mathrm{FeO}-\mathrm{Fe}_{2} \mathrm{O}_{3}-\mathrm{Al}_{2} \mathrm{O}_{3}-\mathrm{TiO}_{2}-\mathrm{SiO}_{2}$ liquids: new measurements and derived partial molar properties, Geochim. Cosmochim. Acta, 51, 2931-2946 
1987.

Melnik, O. and R. S. J. Sparks, Nonlinear dynamics of lava dome extrusion, Science, 402, 37-41, 1999.

Miyagi, I., H. Yurimoto, and E. Takahashi, Water solubility in albiteorthoclase join and JR-1 rhyolite melts at $1000^{\circ} \mathrm{C}$ and 500 to 2000 bars, determined by microanalysis with SIMS, Geochem. J., 31, 57-61, 1997.

Nakada, S. and Y. Motomura, Petrology of the 1991-1995 eruption at Unzen: effusion pulsation and groundmass crystallization, J. Volcanol. Geotherm. Res., 89, 173-196, 1999.

Ohkita, T., M. Kawamura, and S. Takagi, Amount of $\mathrm{SO}_{2}$ emission from Satsuma-Iwojima volcano, Kazan, 22, 107, 1977 (abstract in Japanese).

Ohminato, T. and D. Ereditato, Broadband seismic observation at SatsumaIwojima, Japan, Geophys. Res. Lett., 24, 2845-2848, 1997.

Ono, K., T. Soya, and T. Hosono, Geology of Satsuma-Io-jima district, Quadrangle series, Scale 1:50,000, 2, Geol. Surv. Japan, 80 p., 1982 (in Japanese with English abstract).

Persikov, E. S., The viscosity of magmatic liquids: experiment, generalized patterns, a model for calculation, applications, in Physical Chemistry of Magmas, edited by L. L. Perchuk and I. Kushiro, pp. 1-40, SpringerVerlag, 1990.

Saito, G., K. Kazahaya, H. Shinohara, J. Stimac, and Y. Kawanabe, Variation of volatile concentration in a magma system of Satsuma-Iwojima volcano deduced from melt inclusion analyses, J. Volcanol. Geotherm. Res., 108, 11-31, 2001.

Saito, G., J. A. Stimac, Y. Kawanabe, and F. Goff, Mafic-felsic magma interaction at Satsuma-Iwojima volcano, Japan: Evidence from mafic inclusions in rhyolites, Earth Planets Space, 54, this issue, 303-325, 2002.

Shinohara, H., W. F. Giggenbach, K. Kazahaya, and J. W. Hedenquist, Geochemistry of volcanic gases and hot springs of Satsuma-Iwojima, Japan: Following Matsuo, Geochem. J., 27, 271-285, 1993.
Shinohara, H., K. Kazahaya, and J. B. Lowenstern, Volatile transport in a convecting magma column: Implications for porphyry Mo mineralization, Geology, 23, 1091-1094, 1995.

Shinohara, H., K. Kazahaya, G. Saito, N. Matsushima, and Y. Kawanabe, Degassing activity from Iwodake rhyolitic cone, Satsuma-Iwojima volcano, Japan: Formation of a new degassing vent, 1990-1999, Earth Planets Space, 54, this issue, 175-185, 2002.

Snyder, D. and S. Tait, The imprint of basalt on the geochemistry of silicic magmas, Earth Planet. Sci. Lett., 160, 433-445, 1998.

Stevenson, D. S. and S. Blake, Modelling the dynamics and thermodynamics of volcanic degassing, Bull. Volcanol., 60, 307-317, 1998.

Stolper, E. and J. R. Holloway, Experimental determination of the solubility of carbon dioxide in molten basalt at low pressure, Earth Planet. Sci. Lett., 92, 107-123, 1988.

Wallace, P. J., Volcanic $\mathrm{SO}_{2}$ emissions and the abundance and distribution of exsolved gas in magma bodies, J. Volcanol. Geotherm. Res., 108, 85106, 2001.

Wallace, P. J., A. T. Anderson, and A. M. Davis, Quantification of preeruptive exsolved gas contents in silicic magmas, Nature, 377, 612-616, 1995.

Westrich, H. R. and J. C. Eichelberger, Gas-transport and bubble collapse in rhyolitic magma - an experimental approach, Bull. Volcanol., 56, 447458, 1994.

Yoshida, M. and T. Ozawa, Abundance of some chemical elements produced by Satsuma-Iwo-Jima Volcano in relation to their provenance, Bull. Volcanol. Soc. Japan, 26, 25-34, 1981.

K. Kazahaya (e-mail: kazahaya-k@aist.go.jp), H. Shinohara, and G. 